Doi: HTTPS://DOI.ORG/10.23910/IJEP/2018.5.4.0274

\title{
Valerian and Yarrow: Two medicinal Plants as Crop Protectant Against Late Frost
}

\author{
M. Stefanini, L. Merrien, P. A. Marchand*
}

Institut Technique de l'Agriculture Biologique (ITAB), 149 rue de BERCY, F-75595 Paris CEDEX 12, France

\section{Corresponding Author}

P. A. Marchand

e-mail: patrice.marchand@itab.asso.fr

\author{
Article History \\ Article ID: IJEP0274 \\ Received in $03^{\text {rd }}$ October, 2018 \\ Received in revised form $07^{\text {th }}$ November, 2018 \\ Accepted in final form $21^{\text {st }}$ November, 2018
}

\begin{abstract}
Valerian (Valeriana officinalis L.) and yarrow (Achillea millefolium L.) are well-known medicinal plants that have been widely used in Europe and Asia. In addition to their therapeutic effects, they turn out to be efficient in crop protection. Indeed, extract of their aerial parts are useful in preventive treatment against late frost damages on grapevine, fruit trees and various vegetables. The French Technical Institute of Organic Farming (ITAB) is working for their approbation by the European Union as "basic substance", according to provisions laid down by EC Regulation 1107/2009 on placing plant protection products on the market. Basic Substances represent a new category of plant protection in the European Union. Therefore, a review of available literature was carried out to collect data on their application in plant protection and their toxicological effects. Studies and testimonies showed that valerian and yarrow mixture is efficient in plant protection and the two plant extracts are not of concern.
\end{abstract}

Keywords: Valerian, Yarrow, plant extract, plant protection, elicitor, anti-freezing action, hail damages

\section{Introduction}

Valerian (Valeriana officinalis L.) and yarrow (Achillea millefolium L.) areboth vigorous plant. Valerian is native to Europe and parts of Asia whereas yarrowis native to more continents (Europe, Asia and North America). They are both medicinal plants widely used against many disorders. Valerian underground parts (roots and rhizomes) are known to cure insomnia, to be sedative and to calm gastrointestinal pain, migraine or headache. Yarrow aerial partismainly used for its antispasmodic, digestive and healing properties. Valerian underground parts and yarrow aerial parts belong to European pharmacopeia for their health benefits. However, these two extracts when mixed together turn out to be useful in plant protection, especially in grapevine protection but also for some fruit trees and vegetables as well. This combination mixture is already used by organic farmers, especially by biodynamic winemakers (Masson, 2012) in preventive treatment against damages caused by late frost. Crop yields are particularly threatened during critical budding, blooming and fruiting periods. These usages are significant since grapevine (Vitis vinifera L.) is one of the most economically important fruit species grown around the world. The French Technical Institute of Organic Farming (ITAB) is currently working for the approbation of valerian and yarrow extracts by the European Union to legalize their use in agriculture in Europe as basic substance. This mixture could also be used by worldwide farmers depending on national plant protection products (PPP) regulation.

\section{Materials and Methods}

Available literature on valerian and yarrow application in plant protection, their toxicological and ecotoxicological effects was reviewed. Agronomic field studies of yarrow infusion show slight inhibition of the fungi spore germination whereas valerian preparation is more known to be involved in low temperature management. Most of the known plant components of both valerian and yarrow have been confronted for research of their toxicity and ecotoxicity with the corresponding literature (i.e. against aquatic-, micro-, non-target- and macro-organisms).

\subsection{Application in field}

Data collected are based on biodynamicians testimonies and experience reports. Hot water extractsfor valerian officinaleand for yarrow; both extracts were defined by Rudolf Steiner as biodynamic preparations respectively numbered P507 and P508, for compost. However, these two plants have found many other uses in agriculture (Stefanini, 2017).

Yarrow extract is also used to fight against frost and hail in vineyards. Thus yarrow infusion is known for its help in case of low temperature, but also intended to be used in preventive treatment against the following fungi. 
The utility of valerian preparation against stress after frost, hail and sudden temperature changes is known by some organic farmers, especially biodynamicians. It is described in a book written by Pierre Masson in 2012 (Masson, 2012) and it is advised by many organic associations. It can be used as a preventive treatment against freezing and a curative treatment after hail and sudden temperature changes.

\subsection{Toxicological assessment}

Many studies on valerian root toxicity are available as it is widely used and sold for its medicinal properties. Studies on aerial parts are rare. Therefore, surveys on the main active compounds toxicity have been collected. Some major molecules are specific to valerian such as isovaleric, valeric acid and acetoxy-valerenic acid (Agrobio47, 2012; Brunke, 1993) and other components are also found in many plants such as: camphene, bornyl acetate,chlorogenic acid and apigenin (Li, 2014).

Many studies on yarrow aerial extract were available as it is mainly used in medicine. Studies on major active compounds (clorogenic acid, apigenin, eucalyptol, camphor) (Bertoli, 2012) were also collected.

\subsection{Ecotoxicological assessment}

Data collected concern valerian and yarrow plant ecotoxicological effects but also their major active components. Major components of valerian and yarrow extract are naturally occurring in environmentalready described (US National Library of Medicine, as of 2018). Ecotoxicological data were also found in pharmacological evaluation of these plants for their medicinal properties (EMA, 2010).

\section{Results and Discussion}

\subsection{Application in crop protection}

Valerian aerial part extract is prepared in infusion at $80^{\circ} \mathrm{C}$ or in cold extract with or without maceration. Leaves and flowers can be used in infusion, and flowers can be used as juice or macerated preparation (Agrobio47, 2012; Maille, 2012; Masson, 2012). Yarrow extract is prepared with flowers in infusion at $80^{\circ} \mathrm{C}$ (Masson, 2012).

The mixture of the two extract is used as an elicitor. Indeed, it is known by biodynamicians to possess healing and restorative properties thanks to numerous active molecules such as isovaleric acid and valeric acid in valerian known for their warming faculties (Baudoin, 2015; Maille, 2012). It can be used on plants in case of late frost. Indeed, a preventive treatment the day before or in the morning, just after nights of frost can be applied on grapevines, fruit trees and some vegetables. It allows crops to resist up to $-5^{\circ} \mathrm{C}\left(23^{\circ} \mathrm{F}\right)$. (Agrobio47, 2012; Baudoin, 2015; Maille, 2012; Masson, 2012; Masson, 2016). The valerian effects against frost, hail and sudden temperature changes are efficient on many crops. Translation p. 94 "During the season, if very large thermal amplitudes are observed between day and night, the pulverized valerian preparation alone (preferably in the morning) regulates and alleviates the stress associated with these temperature differences" (Masson, 2012). Valerian extract can be used without yarrow although it is less effective: it only protects plants up to $-3^{\circ} \mathrm{C}$ $\left(26^{\circ} \mathrm{F}\right)$ (Agrobio47, 2012).

Valerian is also efficient as a curative treatment against hail caused damages. This action was observed on grapevine (Baudoin, 2015; Masson, 2016). Indeed, it has been observed that berries at fruit maturation period can heal after hail thanks to the extract regenerative properties (Masson, 2012). An application of yarrow extract just after valerian extract strengthens the curative action (Masson, 2016).

Yarrow infusion intended to be used in preventive treatment against the following fungi: Alternaria solani, the causal agent of early blight in tomatoes; Cladosporium fulvum, the causal agent of tomato leaf mold; Didymella bryoniae, the causal agent of gummy stem blight in the melon; Excerohilumturcicum, the causal agent of Northern leaf blight in Corn; Plasmopara viticola, the downy mildew of wine; Pseudomonas marginalis, the causal agent of cucumber leaf blight; Septoria lycopersici, the causal agent of septoria blight on tomatoes.

\subsection{Toxicological assessment}

According to The European Chemicals Agency (ECHA, 2018), isovaleric and valeric acid contained in valerian can be corrosive and irritant to the skin when highly concentrated (Bingham, 2001; Clayton, 1994). Acetoxyvalerenic acid has a low toxicity (Bos, 1998). Chlorogenic acid, apigenin, bornyl acetate and camphene have no toxic effects. The two latter are classified as flavouring agents and food additives by World Health Organisation (WHO). Chlorogenic acid and apigenin are both absorbed through food and they are known for their anticancer and neuroprotective effects (Li, 2008; Liu, 2005).

Yarrow is considered as "foodstuff" under Regulation EC $178 / 2002$ (EC, 2002) and it is used as an herbal tea against various disorders. According to the European Medicine Agency, Yarrow has no case of acute intoxication neither significant side effect in short term or long-term use. Chlorogenic acid and apigenin also belong to yarrow infusion (Bertoli, 2012). All major active compounds are usually found in food (European Food Safety Authority, 2012). Therefore, active components of valerian and yarrow extracts are not of concern and they exhibit traditional medicinal properties.

\subsection{Ecotoxicological assessment}

Valeriana officinalis is appreciated by bees as it is a melliferous plant (Perisic, 2004) and field of Valeriana officinalis are known to attract earthworms (Kostecka, 2015). Valerian is also used as a natural anthelminthic for ruminants (Duval, 1994). All major compounds are readily biodegradable according to ECHA registration dossier (Lyman, 1990, ECHA, 2018).Some of the active components have also low toxicity on aquatic organisms according to ECHA and The US National Institute 
of Health and Human Services (Franke, 1994).

Achillea millefolium major active compounds are naturally occurring in the environment are therefore readily biodegradable according to the online information from US National Library of Medicine (NIH, 2018). Yarrow is used in veterinary medicine especially for ruminants and poultryfor the same disorders than human (gastric disorders, wound healing) (Yakhekeshi, 2012; Hemmati, 2002) but also against some viruses (Rezatofighi, 2014). Achillea millefolium plants are also used to feed bees at winter (Marghitas, 2011) and to control the parasitic Varroa mite (Parchin, 2012) and extracts have no herbicidal effect (Cruz, 2000) thus no phytotoxic potential effects. Only eucalyptol shows toxicity to bees at high concentration (Imdorf, 1995). As valerian extract, yarrow extract could be toxic for some aquatic organisms when used very concentrated (Bahabadi, 2014; McBrayer, 2015).

\subsection{Agronomic uses}

The preparation can be used every second day after hail episodes or in preventive treatment against frost until the stress conditions remain.It can be used on many crops especially on grapevines and fruit trees which are highly threatened by frost damages, but also on market vegetables. Mode of application of valerian and yarrow extract is spray on aerial parts. It is applied as a contact product which creates a warming protective sheath all around the plants and helps them to cicatrize. Different original recipes of valerian and yarrow extract are described below (Table 1). Although all extractions are done in water and most with dry plant some are done with fresh plant but final concentrations are quite similar.

\begin{tabular}{lccccccc}
\hline \multicolumn{7}{l}{ Table 1: Recipe for valerian and yarrow extract } \\
\hline Plant & Plant status & Extraction (C) $\mathrm{g}^{-1}$ & $\mathrm{Temp}^{\circ} \mathrm{C}$ & Extraction duration & Dilution & Dilution factor & Final (C) $\mathrm{g}^{-1}$ \\
\hline \multirow{2}{*}{ Valerian } & Fresh & 25 & $100^{\circ} \mathrm{C}$ & $10^{\prime}$ & Yes & 20 & 1.25 \\
& Dry & 10 & $80^{\circ} \mathrm{C}$ & $10^{\prime}$ & No & - & 10 \\
\multirow{2}{*}{ Yarrow } & Dry & 3 & $80^{\circ} \mathrm{C}$ & $60^{\prime}$ & No & - & 3 \\
& & 20 & $1000^{\circ} \mathrm{C}$ & $10^{\prime}$ & Yes & 10 & 2 \\
\hline
\end{tabular}

On grapevine (Vitis vinifera), valerian extract is applied from the growth stage budding to 6 leaves (BBCH stage 07 to 16). The application rate treatment is from 50 to $125 \mathrm{~g} \mathrm{hl}^{-1}\left(50 \mathrm{~g} \mathrm{hl}^{-1}\right.$ for flowers extract and $125 \mathrm{~g} \mathrm{hl}^{-1}$ for leaves extract) with water from 100 to $300 \mathrm{I} \mathrm{ha}^{-1}$. The substance is therefore applied from 50 to $375 \mathrm{~g} \mathrm{ha}^{-1}$. Yarrow extract application rate treatment is $2.5 \mathrm{~kg} \mathrm{hl}^{-1}$ with water from 100 to $300 \mathrm{l} \mathrm{ha}^{-1}$. The substance is therefore applied from 2.5 to $7.5 \mathrm{~kg} \mathrm{ha}^{-1}$.

On fruit trees for example apple trees (Malus domestica), valerian extract is applied from the growth stage when majority of petals are fallen (BBCH55 to $\mathrm{BBCH67)}$. The application rate treatment is from 50 to $125 \mathrm{~g} \mathrm{hl}^{-1}\left(50 \mathrm{~g} \mathrm{hl}^{-1}\right.$ for flowers extract and $125 \mathrm{~g} \mathrm{hl}^{-1}$ for leaves extract) with water from 500 to $1500 \mathrm{I} \mathrm{ha}^{-1}$. Therefore, the substance is applied from $250 \mathrm{~g} \mathrm{ha}^{-1}$ to $1.9 \mathrm{~kg} \mathrm{ha}^{-1}$. Yarrow application rate is $2.5 \mathrm{~kg} \mathrm{hl}^{-1}$ with water from 200 to $400 \mathrm{I} \mathrm{ha}^{-1}$. Therefore, the substance is applied form 5 to $10 \mathrm{~kg} \mathrm{ha}^{-1}$. Agronomical uses corresponding to plant protection usages are detailed in the following Good Agricultural Practices (GAP) Table for the fighting against freeze (Table 2).

Table 2: GAP Table for valerian and yarrow extract against freeze

\begin{tabular}{|c|c|c|c|c|c|}
\hline Crop & Extract & Mode of application & BBCH Stage & Application rate $\mathrm{kg} \mathrm{ha}^{-1}$ & Treatment volume I ha-1 \\
\hline Grapevine & Valerian & Foliar spraying & 07 to 16 & 0.05 to 0.375 & 100 to 300 \\
\hline Vitis vinifera & Yarrow & & & 2.5 to 7.5 & \\
\hline Apple trees & Valerian & & 55 to 67 & 0.25 to 1.9 & 500 to 1500 \\
\hline Malus domestica & Yarrow & & & 5 to 10 & 200 to 400 \\
\hline
\end{tabular}

Finally, valerian and yarrow extract can also be used on sensitive vegetables such as beans (Phaseolus vulgaris), basil (Ocimumbasilicum), tomatoes (Solanum lycopersicum), and potatoes (Solanum tuberosum) during spring. Quantities applied are the same as for fruit trees.

The mixture is efficient when it is mixed in proportions $1: 1$. Yarrow extract is also efficient to control insect pests (Jovanovic, 2007; Hasheminia, 2011) and some fungi (Masson, 2012) such as downy mildew on grapevine.

Valerian and yarrow extracts were considered to be eligible as basic substances as they comply with Article 23 criteria of the EC Regulation 1107/2009. Yarrow extract was therefore submitted as a basic substance application (BSA), and declared admissible in 2016 (Marchand, 2015). Approval is awaiting vote at PAFF committee according to the EU official vote procedure. Similarly, corresponding BSA (Marchand, 2016, 2017a) for the valerian extract was constituted and is actually under submission. Following, the Usage in organic farming in EU should be straightforward in EU according to Organic Production regulation (EU, 2016; Marchand, 2017b, 2018). 


\section{Conclusion}

In order to protect crops and to limit yield losses during late frost and after hail, effective and environmentally friendly approaches must be found. Mixture of both valerian and yarrow extracts can be used as an anti-stress and elicitor when late frost occurs and the combination is more effective than individual treatment. The uses of these plant extracts in crop protection are both environmentally friendly and safe for humans. Attempt to recognize them as plant protection means is underway.

\section{Acknowledgment}

This work was made possible by public funding: investigation project about approval at EC regulation 1107/2009 was initially funded by French Ministry of Ecology-DGPR (Direction Generale de la Prevention de Risques) (CP ITAB PNPP V14 2611-10, 2010-12) and ONEMA (Office National de l'Eau et des Milieux Aquatiques) for later funding (PARMA: Programme $d^{\prime}$ approbation et de regularisation de matieres alimentaires, action 17B, 2014-2016).

\section{References}

Agrobio47, 2012. Guide technique des préparations à base de plantes. Comment soigner les plantes par les plantes, 1-28.

Bahabadi, M.N., Banaee, M., Taghiyan, M., Haghi, B.N., 2014. Effects of dietary administration of yarrow extract on growth performance and blood biochemical parameters of rainbow trout (Oncorhynchus mykiss). International Journal of Aquatic Biology 2(5), 275-285.

Baudoin, G., 2015. Entretien avec Didier de la Porte sur le Calendrier des semis (La valeriane officinale. fromJ. Bockemühlin Calendrier des semis 2008 : et des travaux d'agriculture, de jardinage, de viticulture, de sylviculture et d'apiculture bio-dynamiques / Maria Thun et Matthias K. Thun, 1, 1-104; with contributions from Mouvement de culture bio-dynamiqueteam and in Plantes et paysages. éd. MABD, Art du jardin, Biodynamis,vol. 91.

Bertoli, A., Conti, B., Mazzoni, V., Meini, L., Pistelli, L., 2012. Volatile chemical composition and bioactivity of six essentials oils against the stored food insect Sitophilus zeamaisMotsch (Coleoptera dryophthoridae). Natural product research 26(22), 2063-2071.

Bingham, E., Cohrssen, B., Powell, C.H., 2001. Patty's Toxicology Volumes 1-9 5th ed. John Wiley \& Sons. New York, N.Y., 6-432.

Bos, R., Hendriks, H., Scheffer, J.J.C., Woerdenbag, H.J., 1998. Cytotoxic potential of valerian constituents and valerian tinctures. Phytomedicine 5(3), 219-225.

Brunke, E.J., Hallerschmidt, F.J., Schmaus, G., 1993. Flower scent of some Traditional Medicinal Plants. ACS Symposium Series; American Chemical Society 525(20), 282-296.
Cruz, M.E.S., Schwan-Estrada, K.R.F., Nozaki, M.H., Batista, M.A., Stangarlin, J. R., 2000. Alelopatia do extratoaquoso de plantas medicinais na germinacao de sementes de picão. In I Latin-American Symposium on the Production of Medicinal, Aromatic and Condiments Plants 569, 235-238.

Clayton, G.D., Clayton F.E. (Eds.), 1994. Patty's Industrial Hygiene and Toxicology. Volumes 2A, 2B, 2C, 2D, 2E, 2F: Toxicology. $4^{\text {th }}$ Ed. New York, NY: John Wiley \& Sons Inc., 1993-1994., 3529.

Duval, J., 1994. Moyens de lutte contre les parasites internes chez les ruminants. Ecological Agriculture Projects. Agro-bio-370-04.Available from https://eap.mcgill.ca/ agrobio/ab370-04.htmAccessed in October 2018

ECHA, 2018. European chemicals Agency. Registration dossier for Camphene, Bornyl acetate, ApigeninChlorogenic acid, isovaleric acid and valeric acid.Available from

https://echa.europa.eu/fr/information-on-chemicals/ registered-substancesAccessed in October 2018

EMA, 2010. European Medicine Agency.Assessment report on AchilleamillefoliumL. herba. EMA/HMPC/290309/2009. Available from https://www.ema.europa.eu/ documents/herbal-report/draft-assessment-reportachillea-millefolium-I-herba_en.pdfAccessed in October 2018

EC, 2002. Regulation (EC) No 178/2002 of the European Parliament and of the Council of 28 January 2002 laying down the general principles and requirements of food law, establishing the European Food Safety Authority and laying down procedures in matters of food safety, 7, L 31, of 1.2.2002, 1-24.

EU, 2016. Commission Regulation (EU) 2016/673 of 29 April 2016 amending Regulation (EC) No 889/2008 laying down detailed Commission Implementing Regulation rules for the implementation of Council Regulation (EC) No 834/2007 on organic production and labelling of organic products with regard to organic production, labelling and control). L 116, of 30.4.2016, 8-22.

Franke, C., Studinger, G., Berger, G., Bohling, S., Bruckmann, U., Cohors-Fresenborg, D., Johncke, U., 1994. The assessment of bioaccumulation. Chemosphere 29, 1501-14

Hasheminia, S.M., Sendi, J.J., Jahromi, K.T., Moharramipour, S., 2011. The effects of Artemisia annua $\mathrm{L}$ and Achillea millefolium L. crude leaf extracts on the toxicity, development, feeding efficiency and chemical activities of small cabbage Pieris rapae L. (Lepidoptera: Pieridae). Pesticide Biochemistry and Physiology 99(3), 244-249.

Hemmati, A.A., Arzi, A., Amin, M., 2002. Effect of Achilleamillefolium extract in wound healing of rabbit. Journal of Natural Remedies 2(2), 164-167.

Imdorf, A., Kilchenmann, V., Bogdanov, S., Bachofen, B., Beretta, C., 1995. Toxizitat von thymol, campher, menthol und eucalyptol auf Varroa jacobsoni Oud. und Apis mellifera. Apidologie 26, 27-31. 
Jovanovic, Z., Kostic, M., Popovic, Z., 2007. Grain-protective properties of herbal extracts against the bean weevil Acanthoscelides obtectus Say. Industrial crops and products 26(1), 100-104.

Kostecka, J., Carg, V.K., 2015. Use of various baits for extraction of earthworms from vermicompost. Journal ofEcological Engineering 16(5), 87-92

Li, Y., Shi, W., Li, Y., Zhou, Y., Hua, X., Song, C., Ma, H., Wang, C., Li, Y., 2008. Neuroprotective effects of chlorogenic acid against apoptosis of PC12 cells induced by methylmercury. Environmental Toxicology and Pharmacology 26, 13-21.

Li, W.L., Li, M.J., Pan, Y.L., Huang, B.K., Chu, Q.C., Ye, J.N., 2014. Study on electrochemical profiles of Valeriana medicinal Plants. ISSN 10619348. Journal of Analytical Chemistry 69(2), 179-186.

Liu, L.Z., Fang, J., Zhou, Q., Hu, X., Shi, X., Jiang, B.H., 2005. Apigenin inhibits expression of vascular endothelial growth factor and angiogenesis in human lung cancer cells: implication of chemoprevention of lung cancer. Molecular pharmacology 68(3), 635-643.

Lyman, W.J., Reehl, W.E., Rosenblatt, D.H., 1990. Handbook of Chemical Property Estimation Methods. Washington, DC: American Chemical Society, 4-9.

Maille, E., 2012. Fiche Valeriane ${ }^{\circ} 5$. AgroBio Perigord. p.1 Available from http://www.agrobioperigord.fr/upload/ fiche-5-valerianne-2012.pdf Accessed in October 2018

Marchand, P.A., 2015. Basic substances: an opportunity for approval of low-concern substances under EU pesticide regulation. Pest Management Science 71(9), 1197-1200.

Marchand, P.A., 2016. Basic substances under EC 1107/2009 phytochemical regulation: experience with non-biocide and food products as biorationals. Journal of Plant Protection Research 56(3), 312-318.

Marchand, P.A., 2017a. Basic substances as renewable and affordable crop protection products. Chronicle of Bioresource Management 1(2), 065-066.

Marchand, P.A., 2017b. Basic Substances under EU Pesticide Regulation: an opportunity for Organic Production? Organic Farming 3(1), 16-19.

Marchand, P.A., 2018. Novel plant protection regulation: new perspectives for Organic Production? Organic Farming 4(1), 3-6.
Marghitas, L., Dezmirean, D., Chirila, F., Fiț, N., Bobis, O., 2011. Antibacterial Activity of Different Plant Extracts and Phenolic Phytochemicals Tested on Paenibacillus Larvae Bacteria. Animal Science and Biotechnologies 44(2), 94-99.

Masson, P., 2012. Le guide pratique de la biodynamie a l'usage des agriculteurs. Ed. BioDynamie Services, 1-224.

Masson, P., Masson, V., 2016. Fiche technique gelées de printemps.BioDynamie Service, 1-2.

Masson, P., Masson, V., 2016. Fiche technique grele. BioDynamie Service, 1.

McBrayer, M.A., Hays, K., 2015. Determining an LC50: Acute Toxicity of Yarrow (Achillea millifolium) Essential Oils on Daphnia magna. SEEC 2015 Poster Abstracts, 20-21.

$\mathrm{NIH}, 2018$. US National Library of Medicine. National Institute of Health, Health and Humans Services. Toxnet database. Available from https://toxnet.nlm.nih.gov/ Accessed in October 2018

Parchin, R.A., Bahraminejad, S., Parchin, M.A., Ebadollahi, A., 2012. Toxic effect of a selection of medicinal plant products against the parasitic bee mite Varroadestructor. Journal of Medicinal Plants Research 6(14), 2807-2811.

Perisic, S., MacukanovicJocic, M.P., Karadzic, B., Durdevic, L., 2004. The forest melliferous flora in the vicinity of Blace, Serbia. Archives of Biological Sciences 56(1-2), 39-44.

Rezatofighi, S.E., Seydabadi, A., Nejad, S.M.S., 2014. Evaluating the Efficacy of Achillea millefolium and Thymus vulgaris extracts against Newcastle Disease Virus in Ovo. Jundishapur Journal of Microbiology 7(2), e9016.

Stefanini, M., Merrien, L., Marchand, P.A., 2017. La Valeriane et I'Achillée millefeuille : Deux preparations biodynamiques contre les stress climatiques, deux extraits à homologuer en tant que Preparations Naturelles Peu Préoccupantes (PNPP). Biodynamis 40, 17-18.

Yakhkeshi, S., Rahimi, S., HematiMatin, H.R., 2012. Effects of yarrow (Achillea millefolium L.), antibiotic and probiotic on performance, immune response, serum lipids and microbial population of broilers. Journal of Agricultural Science and Technology 14(4), 799-810. 